\title{
潮流発電装置を複数配置した流場影響評価に関 する基礎的研究
}

\author{
渡邊 由香 1 ・居駒 知樹 $2 \cdot$ 増田 光一 $3 \cdot$ 惠藤 浩朗 4 \\ ${ }^{1}$ 日本大学大学院理工学研究科 海洋建築工学専攻 († 274-8501 千葉県船橋市習志野台 7-24-1) \\ E-mail: csuk14003@g.nihon-u.ac.jp \\ 2 正会員 日本大学理工学部教授 海洋建築工学科 (†274-8501 千葉県船橋市習志野台 7-24-1) \\ E-mail: ikoma.tomoki@nihon-u.ac.jp \\ 3 正会員 日本大学理工学部教授 海洋建築工学科 (†274-8501 千葉県船橋市習志野台 7-24-1) \\ E-mail: masuda.koichi@nihon-u.ac.jp \\ ${ }^{4}$ 日本大学理工学部准教授 海洋建築工学科 ( $=274-8501$ 千葉県船橋市習志野台 7-24-1) \\ E-mail: eto.hiroaki@nihon-u.ac.jp
}

本研究は , ファンモデルとポーラスメディアを用いて潮流発電装置を簡易的に模擬し，流況について考 察した . ポーラスメディアはブレードの回転影響を考慮することができないが, ファンモデルはブレード 形状を詳細に定義せずにモデル化でき，さらに回転影響を考慮することができるため，周辺の流場解析に 適していると考えられる .ただし , ファンモデルの場合 , モデル通過後の流速が増加するためポーラスメ ディアによるエネルギー滅衰を人工的に与えた。

本手法を用いて複数のモデルを配置し，装置間の流況について考察したところ，モデル後方 20D で流入 速度の $98 \%$ まで回復することが確認できた .さらに , 流入方向に対して垂直に配置した場合には , 装置間 を1.5Dにすると流入速度と同じになることが確認できた。

Key Words : tidal energy, array, fan model, porous media, CFD

\section{1. 緒言}

潮流発電に関する研究は世界の潮流試験サイトで行 われており, 単体のデバイスにおいては実機サイズを想 定して実証試験力行われている. 弚の中でも水平軸型水 車による研究開発が主に実施されており, ファーム化の 計画がヨーロッパを中心に挙げられる.例えばイギリス のスコットランド西海岸のIslay海峡ではHammerfest Storm社が2003年から2009年にノルウェーで実海域実験 で使用された海底設置型3枚翼のプロペラ式潮流発電を 10機配置した10 MWのアレイ潮流発電ファームのプロ ジェクトか実施されている1). 光の他にもオークニー諸 島のPentland Firth海峡では第一段階として86 MW級、第 二段階では2020年までに398 MW級の潮流発電ファーム 化を目指している2) . いずれもAtlantis Resources社が2010 年にEMECで実施された後継機モデルを用いたものであ る.

弚の他にもフランスの北西部Raz Blanchardで1機あた り1.4 MWを4機配置した総発電量5.6 MW級のパイロッ トプロジェクトを実施し ${ }^{3)}$ ，20年間の稼働を目標として
いる

このように欧州では装置単体の開発だけでなくファ 一ム化計画力数多く進められており，アレイ方法に関す る評価法についての研究力報告されている. Myers et al. ${ }^{4)}$ はアクチュエータディスクを複数用いた水槽実験を実施 し , ディスク間の干渉影響とウェーク領域についての検 討を行った . また , Malki et al. ${ }^{5}$ は3枚翼の水平軸型水車を 想定した複数機配置のデバイス間干渉について BEM-CFD (翼素運動量理論と数值シミュレーション) を用いて評価した，关の結果，発電装置の配置間融を参 考にすることができ，さらに複数配置した際の計算に適 した手法であることを示した .

日本では欧州に比へ実用規模での開発が行われてい ないが, 潮流エネルギーのポテンシャルか高いとされて いることから水平軸型や垂直軸型水車の研究力行われて いる.いずれもファーム化を考えた場合には装置間融を 把握するためにデバイスの後流状況評価を行う必要があ る . そ穴たためには , 水平軸型や垂直軸型などの種類に問 わず，翼形状を含めた計算格子を再現してロータを回転 させる必要がある.しかしながら 数值力学的手法(CFD) 
は物体の動きを考慮しながらの流場解析には膨大な計算 時間を要することから特に装置を複数配置した流場解析 を行うためには, 計算対象とするモデル化の工夫が必要 となる。

そこで本研究では, ファンモデルとポーラスメディア を用いて水車の簡易モデル化を実施し，本モデルを用い て水車をアレイに配置した際の周辺流場を再現した後流 状況評価を実施した 。

\section{2. 研究方法}

\section{(1) 解析方法}

流況の解析には汎用熱流体解析ソフト FLOW- $3 \mathrm{D}^{\circledR}$ Ver.11.06)使用した .これは自由表面解析機能と柔軟で ロバスト性か高い移動物体の取り扱いに有するものに使 用されている.運動方程式にはNavier-Stokes (N-S)方程式 が用いられている. 本解析では, 流体を一定の温度の非 圧縮性流体として扱い, 自由表面の追跡手法には気体側 の移動特性を自由表面上の境界条件に置き換えるVOF 法を用いて解析を実施した . 非圧縮生流体に対する流れ の基礎式は(1)式と(2)式に示すように質量保存式として 連続の式と運動量保存式としてN-S方程式が用いられる. ここで, $u:$ 流速 $, t:$ 時間, $\rho:$ 流体密度 $, \mu:$ 粘性係数, $P:$ 圧力 $, G:$ 加速度である。

$$
\nabla \cdot u=0
$$

$$
\frac{\partial u}{\partial t}+(u \cdot \nabla) u=G-\frac{1}{\rho} \nabla P+\frac{\mu}{3 \rho} \nabla(\nabla \cdot u)+\frac{\mu}{\rho} \nabla^{2} u
$$

\section{(2) ファンモデル}

ファンモデルとは詳細なブレード形状を定義せずに 運動量ソースと抵抗を与えることでモデル化できる .こ のモデルは旋回流速度と軸流速度の両方の成分を生じさ せることができるものである .これによりファン周辺の 流れを簡便に効率よく計算することが可能となる．

本モデルの特徵として以下の点か学げられる .

- 幾何形状は, 回転軸に対して軸対称形状を想定し， ファンは円筒状の回転領域として定義

- 障害物の体積的な閉塞効果は無視

代表的なファンの性能曲線について図 1に示す . 縦軽 か圧力 横軸が流量とし 赤い実線がファンの性能曲線， 青(破線がCFD計算上での線形近似曲線となる゙ これは， デバイスを介して発生する圧力低下と平均の流れ速度を 示したものである

回転速度 $S_{d}$, ブレードがもたらす流体運動を制御する 適応係数 $A_{d}$, 軸流量を制御する $B_{d}$ のパラメータがファ ンの特性を決定する.ファンモデルの性能にはブレード
の詳細な形状やサイズ，またはブレード数によって左右 されるが光れらを含めて全体的な特性の指標となる図-1 に示すような性能曲線を基準に係数を調整する．この性 能曲線は, 装置全体の厚さにわたる角運動量ソースを等 価圧力損失と関連付けて，断面全体にわたって流量を平 均化することによって算出したものを(3)式に示す.ここ で, $\Delta p$ : インペラを横切る圧力差 , $A_{d}$ : 回転速度に対す る適応係数, $S_{d}:$ 回転速度, $B_{d}$ : 軸流速度の係数, $Q:$ 正 味の流量, $R:$ 外半径, $r$ : 内半径である.(3)式の関係か ら, $\mathrm{y}$ 切片が $\Delta p_{0}, \mathrm{x}$ 切片が $Q_{0}$ の線形曲線が与えられる . これらの值は(4)式や(5)式のようになり、任意の性能曲線 に対する線形近似の性能曲線をモデル化できる .

$$
\begin{gathered}
\Delta p=\rho L A_{d}\left(\frac{2}{3} S_{d} B_{d} R\left(1-\frac{r^{3}}{R^{3}}\right)-\frac{Q}{\pi R^{2}}\right) \\
\Delta p_{0}=\rho L\left(\frac{Q_{0}}{\pi R^{2}}\right) A_{d} \\
Q_{0}=\frac{2}{3} \pi\left(R^{3}-r^{3}\right) S_{d} B_{d}
\end{gathered}
$$

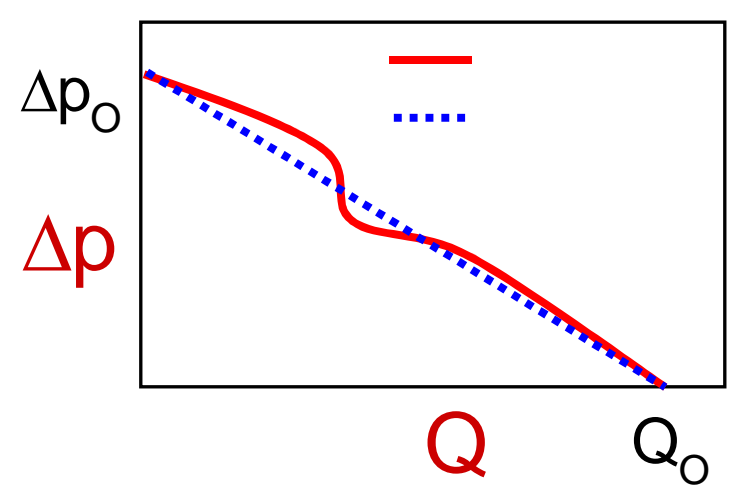

図-1 ファンの性能曲線

ポーラスメディアはブレードの回転影響を考慮するこ とができないがファンモデルの設置により回転影響を考 慮できることから周辺の流場解析に適していると考えら れる.図-2にファンモデル , 図-3にファンモデルとポー ラスメディアを設置した後流影響を示す. 図 2 に示すよ うに, ファンモデルのみの場合, モデル通過後の流速が 増加する .この時の流速を $1 \mathrm{~m} / \mathrm{s}$ とし，回転速度 $S_{d}$ は 3.3 $\mathrm{rad} / \mathrm{s}$, 適応係数 $A_{d}$ を 2.0 , 軸流量係数 $B_{d}$ を 2.0 , 外半径 $R$

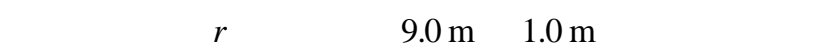
とから，図3に示すようにポーラスメディアを設置する ことでエネルギー減衰を人工的に与え, さらにモデル前 後の圧力差と後流を実際の水車の状況に近づけることと した これにより水車を簡易的に模擬することができる． 


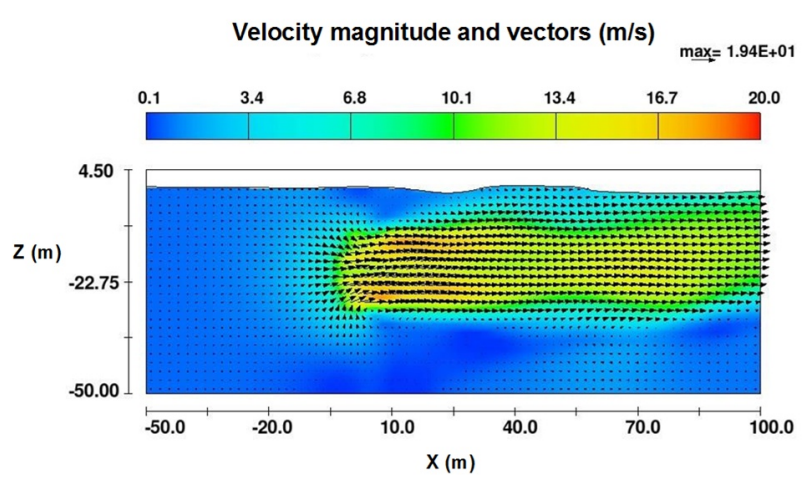

図-2 ファンモデルによる後流影響 $(\mathrm{x}-\mathrm{z}$ 断面)

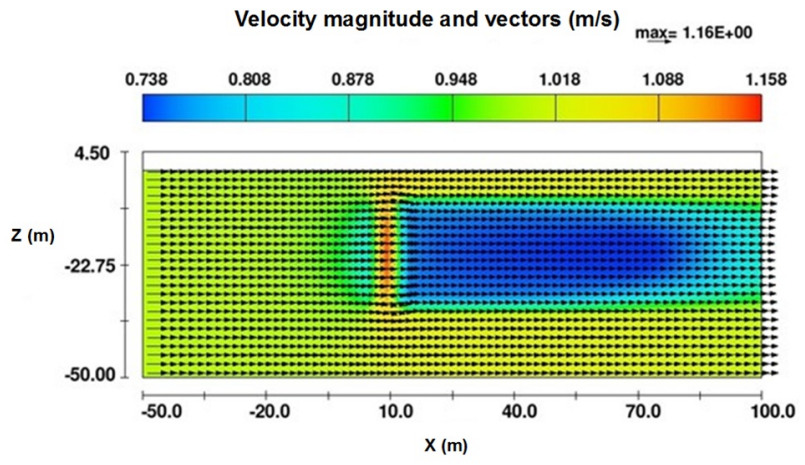

図－３ファンとポーラスメディアによる後流影響 (x-z断面)

\section{3. 数値計算}

(1) ファンモデルとポーラスメディア計算の妥当性

ファンモデルとポーラスメディアを用いた数値計算 の妥当性の検討には, 単機の水平軸型水車による流場特 性の検証を行った .ここでは一樣流速場に単機の水車を 設置し 流況状況を流体一岡体運動連成計算を実施した . これにより流場をシミュレーションすることで単機の水 車か存在する流況を把握した .

本シミュレーションで用いた水車は直径 $18 \mathrm{~m}$,ナセル 直径 $4 \mathrm{~m}$, 長さ $11 \mathrm{~m}$, 水車密度は $4000 \mathrm{~kg} / \mathrm{m}^{3}$ のものとし た . 弚の時の水車モデル概要と炎の周辺の流速べクトル を図 4 に示す . また , ファンの直径を $18 \mathrm{~m}$ ，ポーラス メディアの直径を $20 \mathrm{~m}$ とし，多孔度を 0.8 とした .

計算条件は, 単機の水車とファンモデル・ポーラスメ ディアは同樣とし，流動モ一ドを 1 流体非圧縮生の粘性 流れとした . 表-1に計算条件の詳細を示す .

翼形状を考慮した単体の水車で計算時間が 15 時間 以上かかるのに対して , ファンモデルとポーラスメディ アを用いることで約 $92 \%$ \%時間短縮か泪れることか確 認できた .ただし，単機の水車モデルには機械的な摩擦 抵抗を導入しておらずエネルギ一損失影響のない , パワ 一テイクオフを考慮していない状態とする.図 5には水 平軸型水車とファン・ポーラスメディアの流況比較を示
す .ここで, HAMT (Horizontal Axis Marine Turbine) は 水平軸型水車を示す.図-5の単機水車と検討モデルの流 況の比較から , ファンとポーラスメディア間で流速が速 くなるが, ファン直前とポーラスメディア通過後直後の 流速分布はいずれも減少傾向を示し, 良好な一致を示し ている・よって , ファンモデルとポーラスメディアを用 いた手法は妥当であるとし , 本検討モデルでの実施でき ることか確認できた .

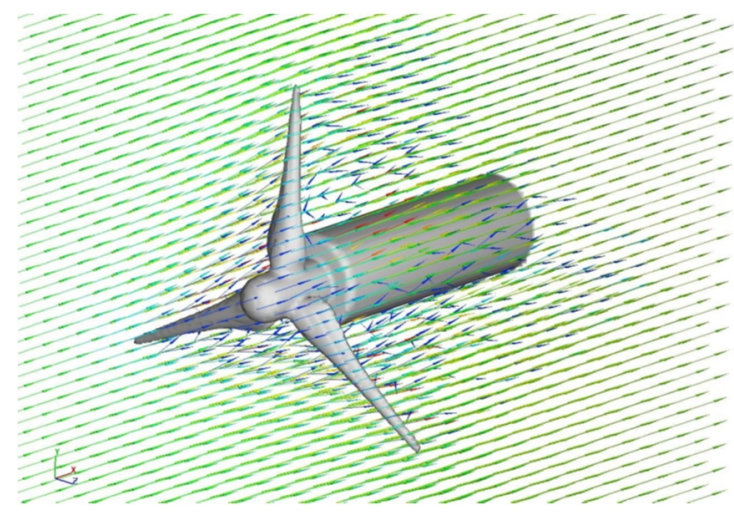

図-4 水車モデルの概要

(水車周辺の流速ベクトル)

表-1 単機水車と検討モデルの計算条件

\begin{tabular}{|c|c|c|}
\hline パラメータ & 単機水車 & 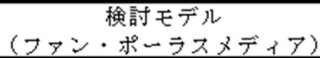 \\
\hline 流速 U & & $1.0 \mathrm{~m} / \mathrm{s}$ \\
\hline 計測時間 $\mathrm{t}$ & & $900 \mathrm{~s}$ \\
\hline 流体の密度 $\rho$ & & $1000 \mathrm{~kg} / \mathrm{m}^{3}$ \\
\hline 長さL & & $1000 \mathrm{~m}$ \\
\hline 計算領域幅B & & $200 \mathrm{~m}$ \\
\hline 深さh & & $200 \mathrm{~m}$ \\
\hline 座䅺最小側 & & 流速境界 \\
\hline 境界经件 座標最大側 & & 圧力璄界 \\
\hline 垷界策座標最大側 & & 水面圧力境界 \\
\hline ₹の他 & & 対称境界 \\
\hline モデル直径D & $18 \mathrm{~m}$ & $18 \mathrm{~m} \cdot 20 \mathrm{~m}$ \\
\hline 計算時間 & $15 \mathrm{~h} 30 \mathrm{~min}$ & $1 \mathrm{~h} 20 \mathrm{~min}$ \\
\hline
\end{tabular}

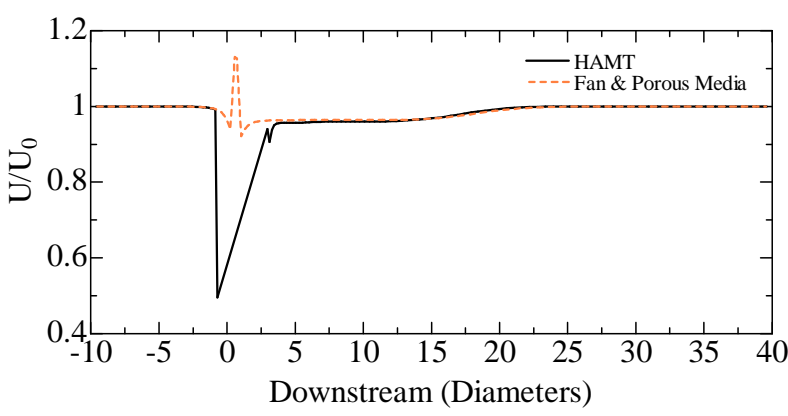

図 5 水平軸型水車とファン・ポーラスメディアの流況比較

(2) ポーラスメディアの設定および流速変化 ポーラスメディアの空隙率はメディア全体の体積て割 った值として定義される.図 6 にポーラスメディアの多 孔度変化による流況比較を示す . 微視的スケールでは空 
隙領域内の速度と圧力分布はかなり複杂倠になるが , 巨視 的な観点から流れを考慮するのであれば, 多孔度の変化 による傾向を確認することか可能であると考える .この 時の流速は $1 \mathrm{~m} / \mathrm{s}$ とし, 多孔度を 0.2 から 0.8 の抵抗係数 を 0.001 ,ファンモデルの条件は前述したとおり回転速度 を $3.3 \mathrm{rad} / \mathrm{s}$ とした .ここで, 横軸はモデル間をモデル直 径で示し 絴軸は自由流速の流速絶対值 $\mathrm{U}_{0}$ とモデルを配 置した場合の流速絶対值 Uて無次元化したものである . その結果, 多孔度の值が小さいぼポーラスメディア通 過後の流速の回復率が遅くなり, さらにファンとメディ ア間の流速が上昇することか確認できる .これはメディ アに流入する透過率が小さなることで, ファンによっ て噴出された流量がポーラスメディアか障害となってモ デル間では流速か㴔激に上昇すると考えられる . また， 多孔度 0.2 の時のポーラスメディア直後の流速傾向は図 - 5 に示す単機水車の流速の減少と比較すると近似傾向 にあることか確認できる．しかし，本条件では流速の回 復が 3 枚翼の水車モデルに比べ遅く，さらに本研究では モデルの後流域の流場解析に着目していることから，本 モデルでの多孔度は 0.8 か妥当であると考えられる．

ここで,流入速度の変化による流況について図-7に示 す .この時のファンとポーラスメディアの大きさは表-1 に示すとおりである.弚の結果, 流速が $1.0 \mathrm{~m} / \mathrm{s}$ ではポー ラスメディア通過後の流速は40D付近で流入速度となる のに対し，流速が $2.0 \mathrm{~m} / \mathrm{s}$ と $3.0 \mathrm{~m} / \mathrm{s}$ では流速の回復か著 しく遅くなることか確認できた .よって，本計算では流 速 $1.0 \mathrm{~m} / \mathrm{s}$ を対象とし検討した .

今後はファンとポーラスメディアの大きさによる違 いや, ファンの回転速度による流況変化の検討を行う必 要がある。

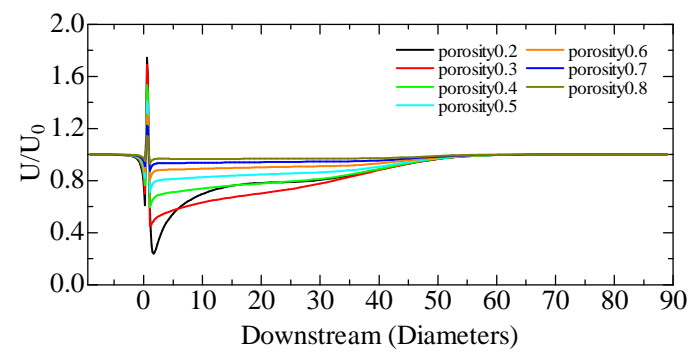

図- 6 ポーラスメディアの多孔度变化による流況比較

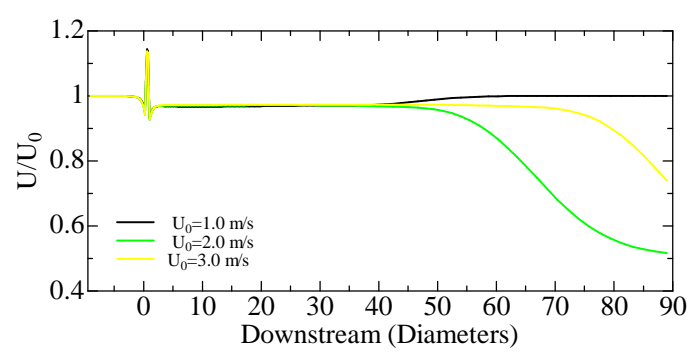

図-7 流速変化による流況比較
(3) 検討モデルのレイアウト

本研究で実施した検討モデルのレイアウトを図 8 に 示す . 図-8a) は検討モデルを流入方向に対して水平に配 置し, 図-8b) は流入方向に対して垂直に配置したもので ある. 光して, 図-8c) は前列に 2 機配置し, 後方に 1 機 配置した千鳥配置したものを示す .この時のモデル間距 離は水平に配置したもので $\Delta \mathrm{x}$ を 10D (D:直径)から 40D とし 垂直に配置したもので $\Delta \mathrm{y} を 0.5 \mathrm{D}$ から 3.0D の 0.5D 間翮の 6 ケースとした . さらに , 千鳥配置したモデルで は前列の配置間融 $\Delta x$ と後方に配置間塥 $\Delta y$ (は図 8a) とb) と同樣とした .

計算領域は長さが $1000 \mathrm{~m}$ ，幅が $400 \mathrm{~m}$ ，深さを $200 \mathrm{~m}$ とし，モデルの設置水深を $100 \mathrm{~m}$ とした .この時の流体 密度は前述したとおり， $1000 \mathrm{~kg} / \mathrm{m}^{3}$, 流速を $1 \mathrm{~m} / \mathrm{s}$, ファ ンモデルの直径を $18 \mathrm{~m}$,ポーラスメディアの直径を $20 \mathrm{~m}$ とし,多孔度を 0.8 , 抵抗係数を 0.001 とした.また，フ

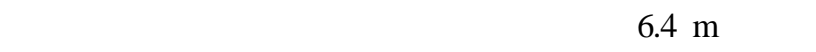
配置間隔も同樣に $6.4 \mathrm{~m}$ とし, 検討モデルの全体長さと して $19.2 \mathrm{~m}$ とした .また，境界条件は表-1に示したとお りである。

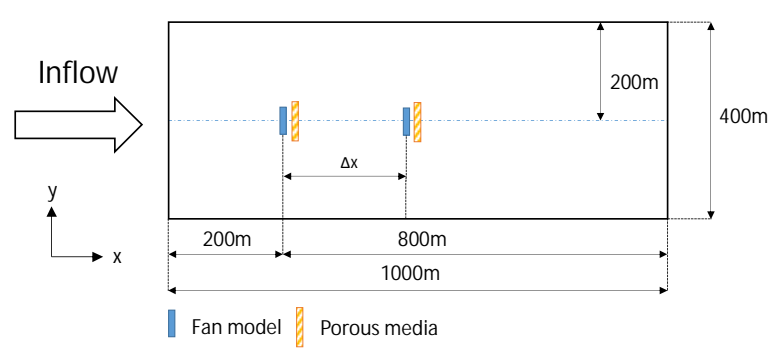

a) 水平配置 (2 機)
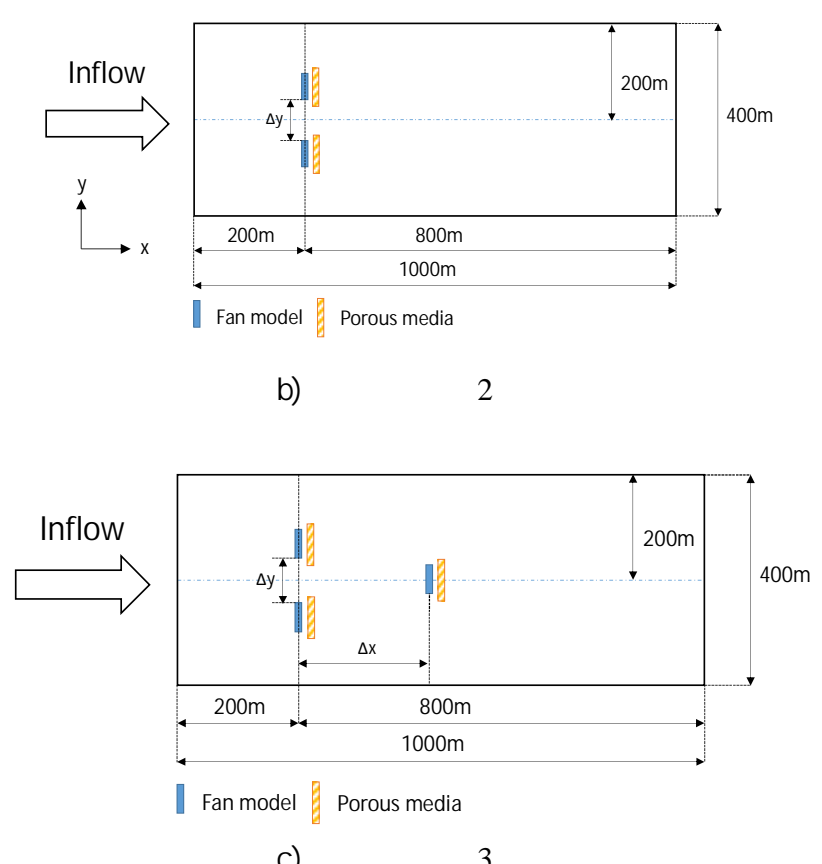

図-8 検討モデルのレイアウト 


\section{4. 検討計算結果}

(1) 検討モデルの流況

本計算ではモデルの配置影響による流況変化につい て3つのレイアウトから明らかにした .図-9(は図-8a)に 示すように流入方向に対して水平にモデル配置した際の 後流速度の結果を示す (2) 項に示す図と同樣に横軸はモ デル間をモデル直径で表記し，縦軸は自由流速の流速絶 対值 $\mathrm{U}_{0}$ とモデルを配置した場合の流速絶対値 U て無次 元化したものである.この時の, 最前列に配置した水車 モデルは 0D の位置とする . モデル間融を 10D にした場

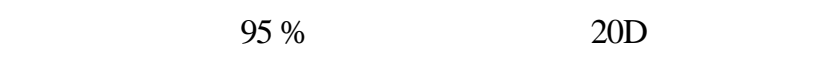
場合には $98 \%$ となる .さらに配置間隔を 20D にした際 の2 機目以降の後流速度は, 55D で流入速度と同じにな ることか確認できた ・いずれもポーラスメディア通過直 前に流速か㴔激に増加するが , これはファンモデルによ る影響のため, 後流域の流況把握には無視することとし た。

図-10a)，b) は図-8b)に示すように流入方向に対して 垂直に配置した際の後方 20D の装置間の流速を示す .点 線はモデル直径の範囲を示している 装置間が $0.5 \mathrm{D}$ から 1.5D の場合 , 20D 後方では装置幅内で流速か洄復しない ことか碓認できた .特に，装置間が $0.5 \mathrm{D}$ の場合では装置 間の干渉によって最も流速の回復が遅いことか確認でき た . 弚こで，図－8c) に示すように垂直にモデルを 2 機配 置し , 後方 40D に 1 機追加した配置した, 計 3 機の千鳥 配置型の後流影響の結果を图-11に示す. 弚の結果，前 列に配置した 2 機の装置間を $0.5 \mathrm{D}$ にすると後方 $40 \mathrm{D}$ で は流入速度の $98 \%$ にるのに対し，装置間を $1.5 \mathrm{D}$ にし た場合 , 流入速度と同じになることか確認できた 。

図-9から図-11の結果より，モデルを複数配置する場 合には垂直配置の間隔を $1.5 \mathrm{D}$ 以上にし，二列目以降の配 置間隔を 20D 以上に設置することで, 流入速度と同じに なり，効率の良い配置間融であると考えられる．今後は 3 機以上配置した場合の，流況影響を検討する必要があ る。

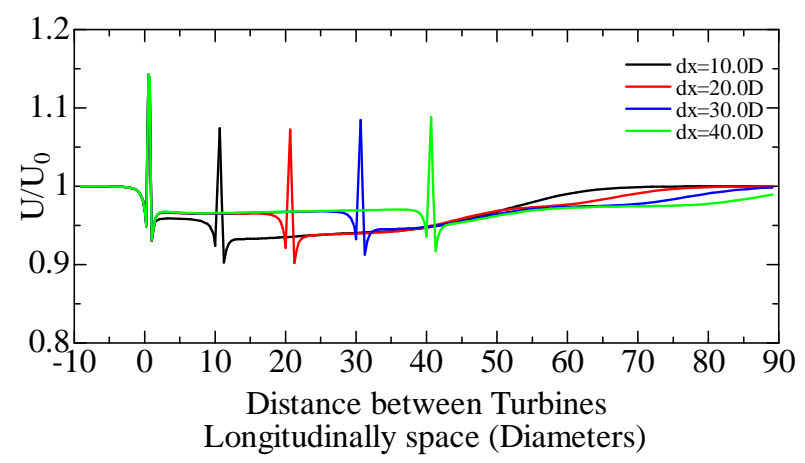

図-9 水平配置モデル 2 機間の後流速度

(10D から 40D)

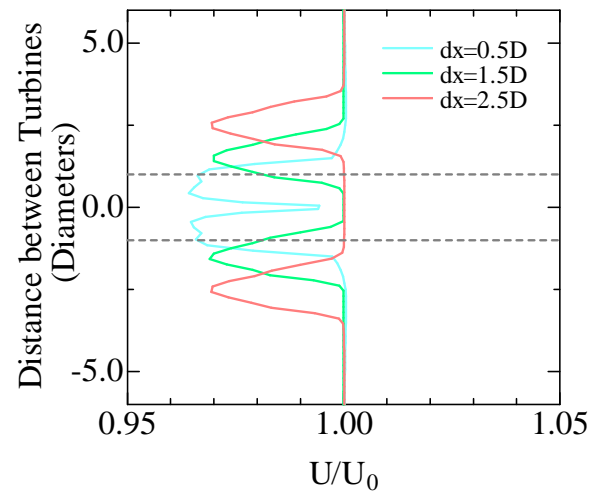

a) $0.5 \mathrm{D}$ から $2.5 \mathrm{D}$

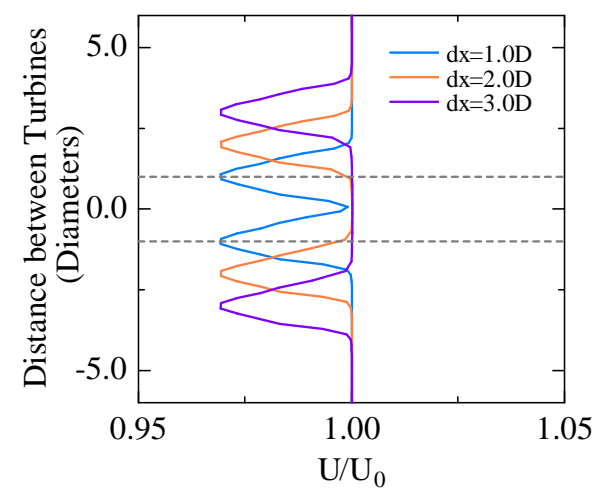

b) $1.0 \mathrm{D}$ から $3.0 \mathrm{D}$

図-10 垂直配置モデル 2 機間の後流速度

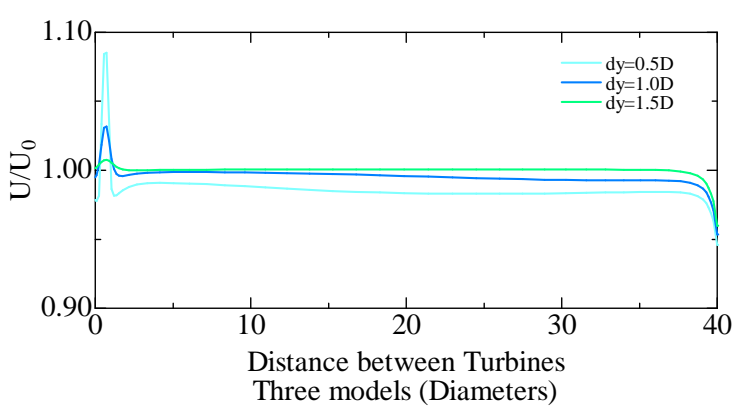

図-11 千鳥配置の後流速度 $0.5 \mathrm{D}$ から $1.5 \mathrm{D}$

\section{5. 結言}

本研究ではファンモデルとポーラスメディアを用い て潮流発電装置を簡易的に模擬し，モデル後流の影響に ついて評価した . 弚の結果，以下のことか確認できた .

1) ファンモデルとポーラスメディアを用いた評価は流 場を簡易的に評価できる手法であることを示した .

2）モデルを流入方向に対して水平に配置した場合、上 流側に配置しているモデル直径の 10 倍 (10D) の後 方では、流入速度が $95 \%$ 程度になり、20D 以上の後 方では流入速度の $98 \%$ まで回復することか確認で 
きた。さらにモデル間を 20D にした場合、モデルの 2 機目以降の後方流速は 55D で流入速度となること か確忍できた。

3）モデルを 3 機千鳥配置にした場合（3 機目を前列か ら 40D 後方の位置に設置)、前列の装置間距離を $0.5 \mathrm{D}$ にすると後方 40D では流入速度の $98 \%$ になる のに対し、装置間距離を $1.5 \mathrm{D}$ にした場合、流入速度 と同じになることか確認できた。

謝辞 : 本研究は, 環境省の平成 27 年度潮流発電技術実用 化推進事業の一部で実施したことを付記し，ここに謝意 を表します。

\section{参考文献}

1) Scottish Power Renewables (2013) Sound of Islay, http://www.scottishpowerrenewables.com/pages/sound_of_islay. asp (2015.5.)
2) International Business Times, "World's Largest Tidal Energy Project To Start Construction Off Scottish Coast This Year", http://www.ibtimes.com/worlds-largest-tidal-energy-project-startconstruction-scottish-coast-year-1668098 (2015.5.)

3) ALSTOM "Alstom chosen to equip pilot tidal farm at raz Blanchard in France", http://www.alstom.com/press-centre/2014/12/alstom-chosen-to-e quip-pilot-tidal-farm-at-raz-blanchard-in-france/ (2015.6.)

4) L.E. Myers and A.S. Bahaj : An experimental investigation simulating flow effects in first generation marine current energy convertor arrays, Renewable Energy 37, Elsevier, pp.28-36, 2012.

5) Rami Malki, Ian Masters, Alison J. Williams and T. Nick Croft : Planning tidal stream turbine array layouts using a coupled blade element momentum - computational fluid dynamics model, Renewable Energy 63, Elsevier, pp.46-54, 2014.

6) $\quad$ FLOW-3D ${ }^{\circledR}$, Ver.11.0, Flow Science Co. Ltd.

(2016.2.4 受付)

\section{A FUNDAMENTAL STUDY OF CURRENT FIELD INFLUENCE WITH MULTIPE TIDAL TURBINES}

\section{Yuka WATANABE, Tomoki IKOMA, Koichi MASUDA and Hiroaki ETO}

This paper discusses the flow field to simulate the tidal power generation device using the fan model and porous media. The porous media is not take into account of the rotation effect of the blades. However, the fan model can be modeled without defining a blade shape in detail and it is possible to further consider the rotation effect. Due to the effect, it is suitable for the surrounding flow analysis. Nevertheless, the flow rate increases artificially in the case of using fan model, so that porous media is used to attenuate energy after passing fan model flow. As a result, around $98 \%$ of inlet velocity recovered in 20D downstream placing longitudinally space. For laterally space, $1.5 \mathrm{D}$ distance between models achieved inlet velocity at $20 \mathrm{D}$ downstream. 